\title{
Hydraulic Resistance and Protein Fouling Resistance of a Zirconia Membrane with a Tethered PVP Layer
}

\author{
Yian Chen ${ }^{1}$ (D), Montserrat Rovira-Bru ${ }^{1,2}$, Francesc Giralt ${ }^{2}$ and Yoram Cohen ${ }^{1, *(D)}$ \\ 1 Water Technology Research Center, Department of Chemical and Biomolecular Engineering, \\ Henry Samueli School of Engineering and Applied Science, University of California, \\ Los Angeles, CA 90095, USA; yianchen@ucla.edu (Y.C.); mrovira@urv.cat (M.R.-B.) \\ 2 Department d' Enginyeria Química, Universitat Rovira i Virgili, 43002 Tarragona, Spain; fgiralt@urv.cat \\ * Correspondence: profyc@gmail.com; Tel.: +1-(310)-713-1543
}

check for updates

Citation: Chen, Y.; Rovira-Bru, M.; Giralt, F.; Cohen, Y. Hydraulic Resistance and Protein Fouling Resistance of a Zirconia Membrane with a Tethered PVP Layer. Water 2021, 13, 951. https://doi.org/ 10.3390/w13070951

Academic Editors: José

Antonio Mendoza-Roca and

Amparo Bes-Piá

Received: 8 March 2021

Accepted: 22 March 2021

Published: 31 March 2021

Publisher's Note: MDPI stays neutral with regard to jurisdictional claims in published maps and institutional affiliations.

Copyright: (c) 2021 by the authors. Licensee MDPI, Basel, Switzerland. This article is an open access article distributed under the terms and conditions of the Creative Commons Attribution (CC BY) license (https:// creativecommons.org/licenses/by/ $4.0 /)$.

\begin{abstract}
The influence of surface modification of zirconia $\left(\mathrm{ZrO}_{2}\right)$ membrane with tethered poly(vinyl pyrrolidone) (PVP) chains was evaluated with respect to the impact of $\mathrm{pH}$ and ionic strength on hydraulic resistance and fouling resistance in the filtration of bovine serum albumin (BSA) and lysozyme (Lys) as model protein foulants. The tethered PVP surface layer led to membrane permeability and fouling propensity that were responsive to both $\mathrm{pH}$ and ionic strength. The PVPmodified membrane ( $\mathrm{PVP}-\mathrm{ZrO}_{2}$ ) hydraulic resistance increased by up to $\sim 48 \%$ over a $\mathrm{pH}$ range of 6-11, but with no discernible impact at lower $\mathrm{pH}$. Membrane hydraulic resistance was virtually unaffected by ionic strength over the 0.001-1 M range. However, reversible foulant cake resistance in BSA and Lys solution filtration increased with elevated ionic strength, owing in part to the weakening of protein-protein repulsion. Irreversible BSA and Lys fouling was affected by the operational $\mathrm{pH}$ relative to the protein isoelectric point (IEP) and reduced under conditions of chain swelling. Irreversible membrane fouling resistance for both proteins was significantly lower, by $\sim 11-49 \%$ and $18-74 \%$, respectively, for the PVP- $\mathrm{ZrO}_{2}$ membrane relative to the unmodified $\mathrm{ZrO}_{2}$ membrane. The present results suggest the merit of further exploration of fouling reduction and improvement of membrane cleaning effectiveness via tuning $\mathrm{pH}$ and ionic strength triggered conformational responsiveness of the tethered target polymer layer.
\end{abstract}

Keywords: ceramic membrane; ultrafiltration; protein fouling; BSA; Lys; cake layer resistance; irreversible fouling resistance; membrane cleaning; graft polymerization; PVP brush layer

\section{Introduction}

The utilization of ceramic ultrafiltration (UF) and microfiltration (MF) membranes has been increasingly promoted in various water treatment applications given their mechanical, thermal, and chemical stability [1,2]. Ceramic membranes can be produced from various materials (e.g., alumina, zirconia, titania, silica and zeolite [3]) with a narrow but well-defined pore size distribution. The porosity of such membranes can be higher, for a given molecular weight cutoff $(M W C O)$, relative to commercially available polymeric membranes [3]. Ceramic membranes hold a smaller share of the membrane market (25\%) relative to polymeric membranes (59\%) [4]. These membranes have been deployed in a broad range of industries such as biotechnology, pharmaceuticals, food and beverage, water purification, wastewater treatment, textile, chemical and petrochemical, semiconductor and microelectronics, metal finishing, and power generation [5-7]. However, as is the case with polymeric membranes [8], fouling, which can degrade membrane performance, remains an operational challenge in the applications of ceramic membranes [9]. Membrane fouling is caused by accumulation and attachment (e.g., adsorption) of foulants onto membrane surface and/or within membrane pores [10]. Fouling is typically classified as reversible and irreversible, the former referring to fouling that can be totally removed by physical cleaning [11], while the latter refers to the foulant portion that requires aggressive 
chemical cleaning for its removal. For example, protein fouling of ceramic membranes has been documented in processes such as mash separation, cold sterilization, and recovery of beer and yeast in the brewing industry [12]. Microbial pore plugging of MF and UF ceramic membranes occurs in the fractionalization of protein in the milk and cheese production processes, and bacterial biofilm formation has been reported in the concentration of defatted whey [13]. Fouling by polysaccharides has also been observed in ceramic membrane treatment of wine microfiltration [14].

Among various ceramic membrane materials, zirconia $\left(\mathrm{ZrO}_{2}\right)$ membranes are of particular interest in the present study. The membranes have good thermal and chemical stability and are of growing popularity in water treatment $[15,16]$, and the food and beverage industries [17]. Various studies have reported on surface modification of zirconia membranes via graft polymerization for imparting stimuli response characteristics $[18,19]$ and fouling reduction $[15,16]$. Various approaches to reduce membrane fouling propensity have been explored including: (i) adjustment of operating conditions (e.g., flux and crossflow velocity); (ii) feed pretreatment (e.g., ozonation, UV oxidation, and flocculation); (iii) periodic membrane cleaning (e.g., backwash, air scrubbing, and chemical cleaning in situ) [11]; and (iv) membrane surface modification to reduce protein-membrane surface interactions [20,21]. Graft polymerization to form tethered layers of hydrophilic polymers has received particular attention for surface modification of both polymeric and ceramic membranes [22,23]. Reported foulant adsorption reduction was attributed to both surface screening by the hydrophilic tethered chains and their partial segment mobility (Brownian motion) [24].

Tethered polymer chains can undergo conformational changes (e.g., chain collapse or swelling) triggered by external environmental stimuli (e.g., solution $\mathrm{pH}$, ionic strength, UV-Vis, temperature, electrical/magnetic field [25]). The stimuli-response of polymeric membranes with tethered polymer brushes has been reported [26] for modulating membrane characteristics such as wettability, pore size or permeability/selectivity [26], and release of surface deposited foulants [27]. Here we note that studies on ceramic membranes with tethered surface polymeric chains have focused primarily on their thermo-responsiveness [18,19]. For example, $\mathrm{ZrO}_{2}$ membrane with tethered poly(N-isopropylacrylamide) had lower flux decline by up to $\sim 40 \%$ and $21.3 \%$ in filtration of bovine serum albumin (BSA) [18] and humic acid (HA) [19], respectively, at $25^{\circ} \mathrm{C}$ relative to $35^{\circ} \mathrm{C}$. Cleaning of the fouled membranes with water (for $30 \mathrm{~min}$ ), at $35{ }^{\circ} \mathrm{C}$ and then $25{ }^{\circ} \mathrm{C}$, enabled $80 \%$ and $98 \%$ flux recovery for BSA and HA solutions filtration, respectively $[18,19]$. Flux recovery was only $14 \%$ and $43 \%$ for filtration of BSA and HA solutions, respectively, with the unmodified membranes. It was postulated that tethered chain swelling upon temperature cycling contributed to loosening of the adsorbed foulant layer and thus improved cleaning efficacy.

It was also shown that tethered polyacrylic acid (PAA) on zirconia MF membranes [15] led to fouling reduction in BSA protein filtration. Membrane cleaning was improved enabling up to $53 \%$ greater water flux recovery relative to the unmodified membrane [15]. It is interesting to note that in earlier work adsorption of lysozyme (Lys) onto zirconia particles was significantly reduced when the surface was modified with a tethered poly(vinylpyrrolidone) (PVP) layer [28]. It was postulated that adsorption reduction was due to both zirconia surface screening by the tethered PVP layer and driving the surface charge toward neutral to negative charge. It was also shown that irreversible fouling in the filtration of oil-in-water microemulsions was significantly reduced for Zirconia UF membranes with tethered PVP chains [16,29] compared to unmodified zirconia membrane.

The available studies on adsorption and fouling of ceramic membranes with surface tethered hydrophilic chains suggest that tethered chains can reduce protein fouling and improve membrane cleaning efficacy. Accordingly, in the present work, we explored the impact of a UF zirconia membrane surface modification with tethered PVP brush layer on membrane hydraulic permeability, protein fouling reduction, and membrane cleaning improvement. PVP was selected for membrane surface modification given its watersolubility, hydrophilicity, and biocompatibility [30]. The tethered PVP layer was prepared 
by a two-step process comprising of surface anchoring of a vinyl-silane, followed by graft polymerization of VP onto the active membrane zirconia layer. The study provides a systematic evaluation of the impact of solution $\mathrm{pH}$ and ionic strength on the PVP$\mathrm{ZrO}_{2}$ membrane hydraulic permeability. Using model protein foulants (BSA and Lys), reversible and irreversible fouling resistance were then evaluated, also quantifying the impact of the tethered PVP layer on membrane cleaning efficacy.

\section{Materials and Methods}

\subsection{Materials}

A tubular carbon-supported $\mathrm{ZrO}_{2}$ Carbosep M1 membrane with a manufacturer reported nominal MWCO of $150 \mathrm{kDa}$ (Tech-Sep, Miribel, France) was selected as the base zirconia membrane. The Carbosep M1 membrane, housed in a membrane module (Figure 1a), had outside and inside diameters of $3.00 \mathrm{~mm}$ and $5.29 \mathrm{~mm}$, respectively, and a corresponding $2.75 \mu \mathrm{m}$ zirconia active layer thickness. Cross-sectional and top images of the membrane are shown in Figure 1b,c, respectively. Grafting of the surface vinyl groups was achieved via membrane surface silylation with vinyl-trimethoxy-silane (VTMS, Petrach Systems Inc., Bristol, PA, USA) dissolved in a reagent grade xylene (Fisher Scientific, Tustin, CA, USA). Vinylpyrrolidone (VP) (Kodak Chemical Co., Rochester, NY, USA) was the monomer used for graft polymerization to create a tethered PVP layer onto the zirconia membrane. KOH pellets (Fisher Scientific, Pittsburgh, PA, USA) were used to prepare a $\mathrm{pH} \sim 12$ solution for hydrolysis of the silylated membranes. A $50 \%$ aqueous ammonium hydroxide (Mallinckrodt Inc., Paris, KY, USA) solution was the source of ammonium ions for the graft polymerization reaction. The above solution also served as a buffer for the reaction mixture and for suppressing the formation of acetaldehyde (a by-product that promotes chain transfer [16,31]). Hydrogen peroxide as a $30 \%$ reagent-grade solution (Aldrich Chemical Co., Milwaukee, WI, USA) served as the initiator for VP graft polymerization. Model foulants for the membrane fouling tests were Lys grade I (L87) and grade V protease-free BSA (A3059) (SIGMA, St. Louis, MO, USA). All solutions were prepared using the ultra-pure de-ionized (D.I.) water obtained by filtering distilled water through a Milli-Q Water System (Millipore Corp., San Jose, CA, USA). Solution ionic strength was adjusted using $\mathrm{NaCl}$ (S40-500; Fisher Scientific, Tustin, CA, USA). The protein solution $\mathrm{pH}$ was adjusted with $0.1 \mathrm{M} \mathrm{HCl}$ and $0.1 \mathrm{M} \mathrm{NaOH}$ solutions (Fisher Scientific, Pittsburgh, PA, USA).

\subsection{Surface Modification}

The ceramic membrane (Figure 1) surface was modified by a two-step free-radical graft polymerization process, using the experimental setup shown in Figure 2, following a previously established procedure $[16,28,29]$. Briefly, the initial step was surface vinyl-silylation for covalent attachment of vinyl groups onto the zirconia surface -OH groups. Prior to silylation, in order to remove organic residue from the membrane surface, the base membrane was immersed in a $0.1 \mathrm{M}$ aqueous $\mathrm{NaOH}$ solution at $40{ }^{\circ} \mathrm{C}$ for $40 \mathrm{~min}$. The membrane was subsequently rinsed with D.I. water and again immersed in a $0.1 \mathrm{M} \mathrm{HNO}_{3}$ solution at room temperature for another $40 \mathrm{~min}$. After the above pretreatment, the membrane was thoroughly rinsed with D.I. water and then stored in D.I. water. Subsequently, silylation was carried out (Figure 2) for a period of $5 \mathrm{~h}$ in a 10\% $(v / v)$ solution of VTMS in xylene at $70^{\circ} \mathrm{C}$. The above approach, as confirmed in an earlier study via DRIFT spectroscopy of the silylated zirconia surface [28], results in a VTMS that is covalently attached to the zirconia surface. Subsequently, hydrolysis of the methoxy groups was carried out by immersing the membrane in a stirred $\mathrm{KOH}$ solution at $\mathrm{pH} 12$ for at least $24 \mathrm{~h}$. VP graft polymerization followed at $70{ }^{\circ} \mathrm{C}$ (over a $5 \mathrm{~h}$ period) with a $30 \%(v / v)$ aqueous VP solution, initiated with $2 \mathrm{~mL} \mathrm{H}_{2} \mathrm{O}_{2}$ solution and $0.8 \mathrm{~mL} \mathrm{NH}_{4} \mathrm{OH}$ solution. Both the silylation and graft polymerization steps were performed with the reaction solution mixture circulating through the membrane tube side (Figure 2) using a peristaltic pump (Model 7090-42, Cole Palmer Co., Chicago, IL, USA). 

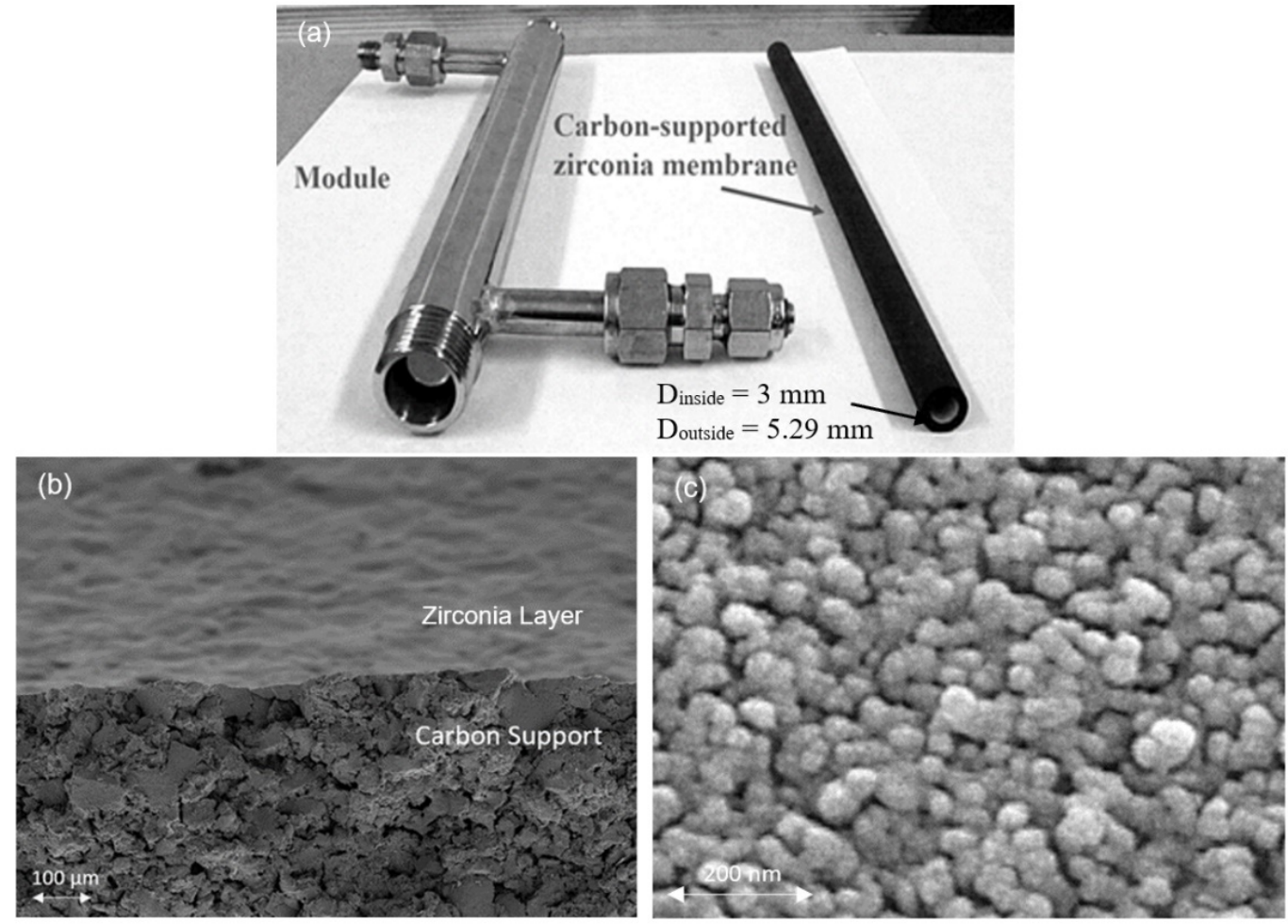

Figure 1. (a) Carbon-supported zirconia membrane and membrane module and Scanning Electron Microscope (SEM) image of the tubular carbon-supported $\mathrm{ZrO}_{2}$ Carbosep M1 membrane showing (b) cross-sectional and top view of the zirconia layer and underlying porous carbon support, and (c) top view of the zirconia layer at high magnification. (The SEM images were obtained using Zeiss Supra VP40 SEM (Carl Zeiss AG, Oberkochen, Germany) with an accelerating voltage of $10 \mathrm{keV}$ and a spot size of 100-10,000 nm. Prior to SEM characterization, the membrane sample was sputter-coated (Hummer ${ }^{\circledR}$ 6.6 Sputter Coater, Anatech USA, Sparks, NV, USA) for 3 min with a thin film of gold (Au) to prevent charging during SEM imaging).

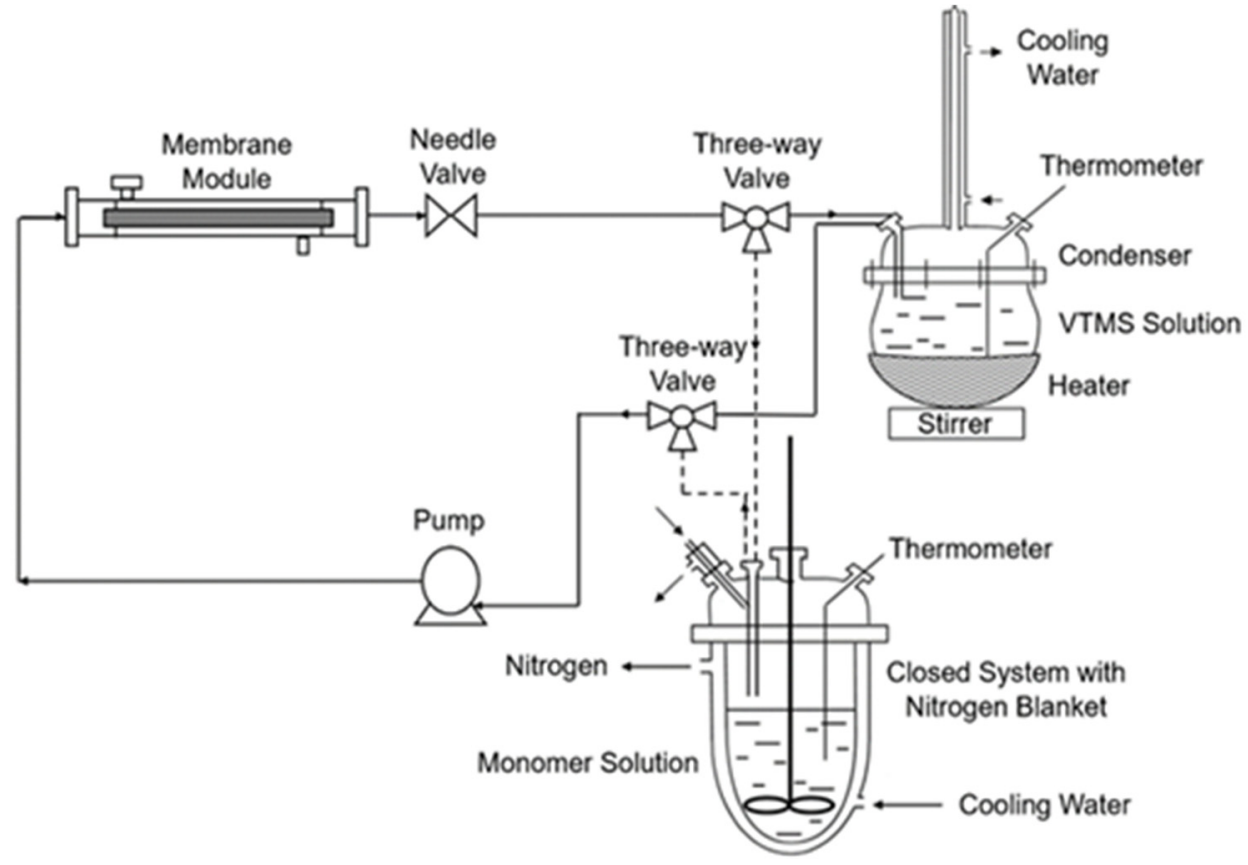

Figure 2. Illustration of the experimental setup for membrane silylation and graft polymerization. Graft polymerization was carried out with the bottom three-way valve directing the monomer solution flow from the monomer reservoir to the membrane module (indicated by the dashed line) and then back to the reservoir via the top three-way valve (following the stream indicated by the dashed line). 
All tubing and the membrane unit were thermally insulated, and both silylation and graft polymerization processes were performed in the absence of permeate flux. This was achieved by sealing the permeate exit connectors and keeping the applied pressure on the tube-side below the capillary pressure associated with the membrane pores. Upon termination of the VP graft polymerization reaction, D.I. water was pumped through the membrane module (under permeation conditions); this allowed permeate flow to quench the reaction. D.I. water flushing of the membrane continued until neutral $\mathrm{pH}$ was reached (i.e., indicating complete removal of the acid or base additives). Subsequently, membrane performance was characterized as described in Section 3.

\subsection{Membrane Hydraulic Resistance and Fouling Test}

Membrane hydraulic resistance and protein fouling impacts were determined via flux decline tests in a crossflow filtration system schematically shown in Figure 3. The solution was delivered, from a temperature-controlled feed reservoir to the membrane module inlet port via a diaphragm pump (Model A304010210, Flojet Corp. Irvine, CA, USA) interfaced with a pulse dampener. A needle valve (Model NV40025T, Hayward Industrial Products, Elizabeth, NJ, USA), at the membrane module exit, enabled adjustment of the membrane transmembrane pressure. The pressure was monitored with pressure transducers (Model DP15-44, Validyne Engineering Co., Northridge, CA, USA, full-scale error of $\pm 0.5 \%$ ) at the membrane module feed- and permeate-sides. The feed and permeate flow rates were monitored by an in-line flow meter (RMB-85-SSV, Dwyer Instruments Co., Michigan City, IN, USA). All membrane tests were carried out in total recycle whereby the retentate and permeate streams were recirculated back to the feed tank.

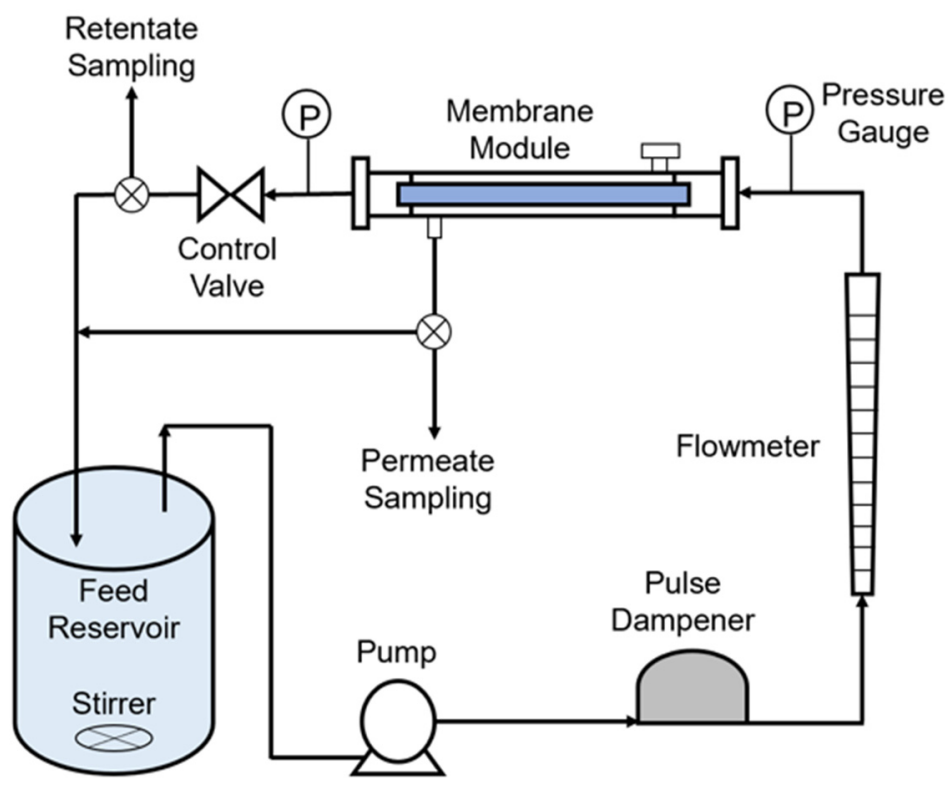

Figure 3. Schematic diagram of the membrane filtration system.

Fouling stress tests were carried out using aqueous solutions of $0.4 \mathrm{~g} / \mathrm{L}$ BSA or Lys at a transmembrane pressure of $30 \mathrm{kPa}$ and $\mathrm{Re}=3600$ (crossflow velocity of $\sim 60 \mathrm{~cm} / \mathrm{s}$ ). The $0.4 \mathrm{~g} / \mathrm{L}$ protein solution concentration was selected given that the adsorption plateau on zirconia is reached at the above concentration for both BSA and Lys (as reported in [28,32]). Operation at the above Reynolds number (highest achievable level with the utilized pump and membrane tube) was carried out to reduce cake formation, and protein layer compaction and denaturation. Operating at the above condition was implemented to enhance the quantification accuracy of irreversible fouling resistances [33]. Therefore, the impact of $\mathrm{pH}$ on membrane fouling in the filtration of BSA and Lys was assessed over $\mathrm{pH}$ ranges of 3.5-7 and 3-10, respectively, at the ionic strength of $0.1 \mathrm{M}$. The $\mathrm{pH}$ range 
is well within the range for applications of membrane filtration in the wine (2-4) [34], dairy (4.5-9.5) [35] and brewing (3-10) [36] industries. Fouling tests were also carried out at $\mathrm{pH} 7$ in the ionic strength range of $0.001-0.5 \mathrm{M}$ to assess the impact of foulant solution ionic strength. The above conditions were within the operating range in applications in the wine (0.01-0.15 M [37]), dairy ( 0.08-0.3 M [38,39]) and beer (0.01-0.5 M [40]) industries.

Both protein concentrations in the feed and permeate streams were determined by UV analysis at $\lambda=280 \mathrm{~nm}$ (HP 8452A Diode Array Spectrophotometer, Hewlett-Packard, Palo Alto, CA, USA). Prior to the termination of each test, protein rejection for the different membranes was calculated as $R=1-C_{p} / C_{f}$, in which $C_{p}$ and $C_{f}$ are the protein concentrations in the permeate and feed solution, respectively. After each filtration test, the membrane was first cleaned with D.I. water to assess the foulant cake resistance. This was then followed by immersion of the membrane in a $0.4 \mathrm{M} \mathrm{NaOH}$ solution containing $1000 \mathrm{ppm} \mathrm{NaOCl}$ at $60^{\circ} \mathrm{C}$ for $1 \mathrm{~h}$. The membrane was subsequently rinsed with D.I. water and again immersed in a $0.4 \mathrm{M} \mathrm{HNO}_{3}$ and $0.1 \mathrm{M} \mathrm{H}_{2} \mathrm{O}_{2}$ solution at room temperature for $1 \mathrm{~h}$. The above procedure enabled complete full membrane permeability recovery.

The hydraulic resistance of a clean membrane, $R_{m}\left(\mathrm{~m}^{-1}\right)$ was determined with D.I. water based on Darcy's law [41]:

$$
J=\Delta P / \mu R_{m}
$$

where $J(\mathrm{~m} / \mathrm{s})$ is the permeate flux, $\Delta P(\mathrm{~Pa})$ is the transmembrane pressure, and $\mu(\mathrm{kg} / \mathrm{m} \cdot \mathrm{s})$ is the permeate viscosity. Membrane permeability was determined from the slope of permeate flux versus transmembrane pressure. Assuming that unmodified and grafted membranes have a similar number of pores and pore lengths, the average grafted membrane pore radius can be estimated using the Hagen-Poiseuille equation [42]. Accordingly, the membrane pore radius is taken to be $\propto 1 /(\text { membrane resistance })^{1 / 4}$ and the average effective pore radius of the modified membrane can be obtained from,

$$
r_{\text {grafted }}=r_{\text {unmodified }} \cdot\left(\left(R_{m}\right)_{\text {unmodified }} /\left(R_{m}\right)_{\text {grafted }}\right)^{0.25},
$$

where $r_{\text {grafted }}$ and $r_{\text {unmodified }}$ are the membrane pore radius of the PVP-grafted and unmodified membranes, respectively, and $\left(R_{m}\right)_{\text {grafted }}$ and $\left(R_{m}\right)_{\text {unmodified }}$ are the corresponding hydraulic resistances of the clean membranes.

The total membrane hydraulic resistance in the fouling tests, $R_{T}$, was determined via flux decline monitoring using the resistance in the series model [43], i.e.,

$$
R_{T}=R_{m}+R_{\text {cake }}+R_{\text {irrev }}
$$

where $R_{\text {irrev }}$ and $R_{\text {cake }}$ are the irreversible fouling and reversible cake layer resistances, respectively. The membrane total hydraulic resistance was determined at the end of each protein filtration test, typically once permeate flux decline approached steady state. Subsequently, D.I. water was circulated through the membrane system until protein traces in the permeate and retentate streams were below the detection limit. The fouled membrane hydraulic resistance was then determined based on the final permeate water flux (after D.I. water cleaning). This resistance is the sum of the membrane and irreversible fouling resistances, i.e., $R_{T}^{\prime}=R_{m}+R_{\text {irrev }}$, given $R_{m}$ for the membrane; $R_{\text {irrev }}$ was then determined, and subsequently, $R_{\text {cake }}$ was calculated given the overall resistance $\left(R_{T}\right)$.

\section{Results and Discussion}

\subsection{Hydraulic Resistance of Native and Modified Zirconia Membranes}

Membrane hydraulic resistance $\left(R_{m}\right)$ was the highest for the VTMS grafted membrane, followed by the hydrolyzed VTMS membrane, the PVP grafted zirconia $\left(\mathrm{PVP}-\mathrm{ZrO}_{2}\right)$ membrane, and the native (unmodified) zirconia membrane (Table 1). $R_{m}$ increased significantly for the VTMS grafted membrane, relative to the unmodified zirconia membrane. This increased membrane hydraulic resistance $\left(R_{m}\right)$ is attributed to replacement of the hydrophilic hydroxyl groups $(-\mathrm{OH})$ with the more hydrophobic methoxy $\left(-\mathrm{OCH}_{3}\right)$ and vinyl $\left(-\mathrm{CH}=\mathrm{CH}_{2}\right)$ groups of the grafted VTMS [28,29]. Indeed, it was reported that the water contact angle 
for VTMS silylated zirconia surface (supported on alumina) was approximately a factor of $\sim 3.7$ higher relative to the unmodified surface [44]. It is also plausible that VTMS grafting at or in proximity of pore openings and/or within the pores (although to a lesser degree; Section 2.2) could have increased the membrane hydraulic resistance. Given the above, it is reasonable to expect that, upon hydrolysis of the surface grafted VTMS methoxy groups, the introduction of hydroxyl groups led to partial restoration of membrane hydrophilicity [45]. The above assertion is supported by the observation of $\sim 40 \%$ lower hydraulic resistance of the hydrolyzed relative to the non-hydrolyzed VTMS modified membrane.

Table 1. Hydraulic resistance of unmodified and modified zirconia Carbosep M1 membranes.

\begin{tabular}{ccc}
\hline Membrane & $\left.\boldsymbol{R}_{\boldsymbol{m}} \mathbf{( 1 0}^{\mathbf{1 2}} \mathbf{~}^{-\mathbf{1}}\right)$ & $\mathbf{R}^{\mathbf{2}(\mathbf{a})}$ \\
\hline Unmodified & 2.75 & 0.9809 \\
Vinyl-trimethoxy-silane (VTMS) Silylated & 16.07 & 0.9879 \\
VTMS/Hydrolyzed & 9.82 & 0.9990 \\
Grafted & 5.99 & 0.9908 \\
\hline
\end{tabular}

(a) $\mathrm{R}^{2}$ of linear plots of $\Delta P / \mu$ versus J (Equation (1); Figure A1, Appendix A).

Upon VP graft polymerization, the tethered PVP chains further decreased PVP- $\mathrm{ZrO}_{2}$ membrane hydraulic resistance (by $\sim 39 \%$ ) relative to the hydrolyzed VTMS membrane. Indeed, previous work has shown that a tethered PVP layer [16] reduced the surface free energy of hydration well below $-113 \mathrm{~mJ} / \mathrm{m}^{2}$, which is the threshold value for classifying hydrophilic and hydrophobic surfaces [46]. The greater $\mathrm{PVP}-\mathrm{ZrO}_{2}$ membrane hydrophilicity relative to the hydrolyzed VTMS grafted zirconia membrane presumably contributed to lowering the former membrane hydraulic resistance (by a factor of 1.6). However, the hydraulic resistance of the PVP-modified membrane remained well above (by a factor of 2.2) that of the unmodified $\mathrm{ZrO}_{2}$ membrane. The thickness of the tethered PVP layer, formed on the zirconia surface at the present reaction conditions, was estimated in previous work to be up to $\sim 10 \mathrm{~nm}$. The above estimate was based on AFM characterization of tethered PVP on smooth ceramic inorganic oxide surface (silicon wafer), and gravimetric analysis of PVP-modified zirconia particles [28,29]. At the above magnitude of tethered PVP layer thickness, it is likely due to pore size reduction owing to the tethered PVP brush layer. Here we estimate that the PVP grafting reduced the unmodified membrane average pore size $(60 \AA)$ by about $18 \%$ as per the approximate analysis presented in Section 2.3 .

Both polymeric and ceramic membranes are used over a wide range of $\mathrm{pH}(2-10)$ in the wine, dairy, and brewing industries [34-36,47]. Over such a wide $\mathrm{pH}$ range, the hydraulic resistance of the unmodified $\mathrm{ZrO}_{2}$ membrane did not reveal a dependence on $\mathrm{pH}$ (Figure 4). In contrast, the hydraulic resistance of the PVP- $\mathrm{ZrO}_{2}$ membrane increased from $3.09 \times 10^{12}$ to $4.71 \times 10^{12} \mathrm{~m}^{-1}$ over the $\mathrm{pH}$ range of $4-11$ (Figure 4). The $\mathrm{PVP}-\mathrm{ZrO}_{2}$ membrane resistance remained virtually invariant over the $\mathrm{pH}$ range of $4-6$, but increased by up to $\sim 53 \%$ as the $\mathrm{pH}$ increased from about 6 to 11. $\mathrm{pH}$-responsiveness of the hydraulic resistance of the PVP- $\mathrm{ZrO}_{2}$ membrane may be attributed to structural rearrangement of PVP brush layer upon protonation/deprotonation of the ionizable side groups [25]. Under basic conditions $(\mathrm{pH}>7)$, the PVP chains will be in a more extended conformation [48] due to electrostatic repulsion between chain segments [49], hence potentially leading to the heightened level of pore narrowing or blockage. It is noted that the above stimuli-responsive PVP brush layer displayed a continuous hydraulic membrane resistance change in response to $\mathrm{pH}$ (Figure 4). This trend is clearly different than the "on-off" permeability "gating switch" that has been reported in the literature for stimuli-responsive membranes surface modified with tethered polymeric brush layers [49]. 


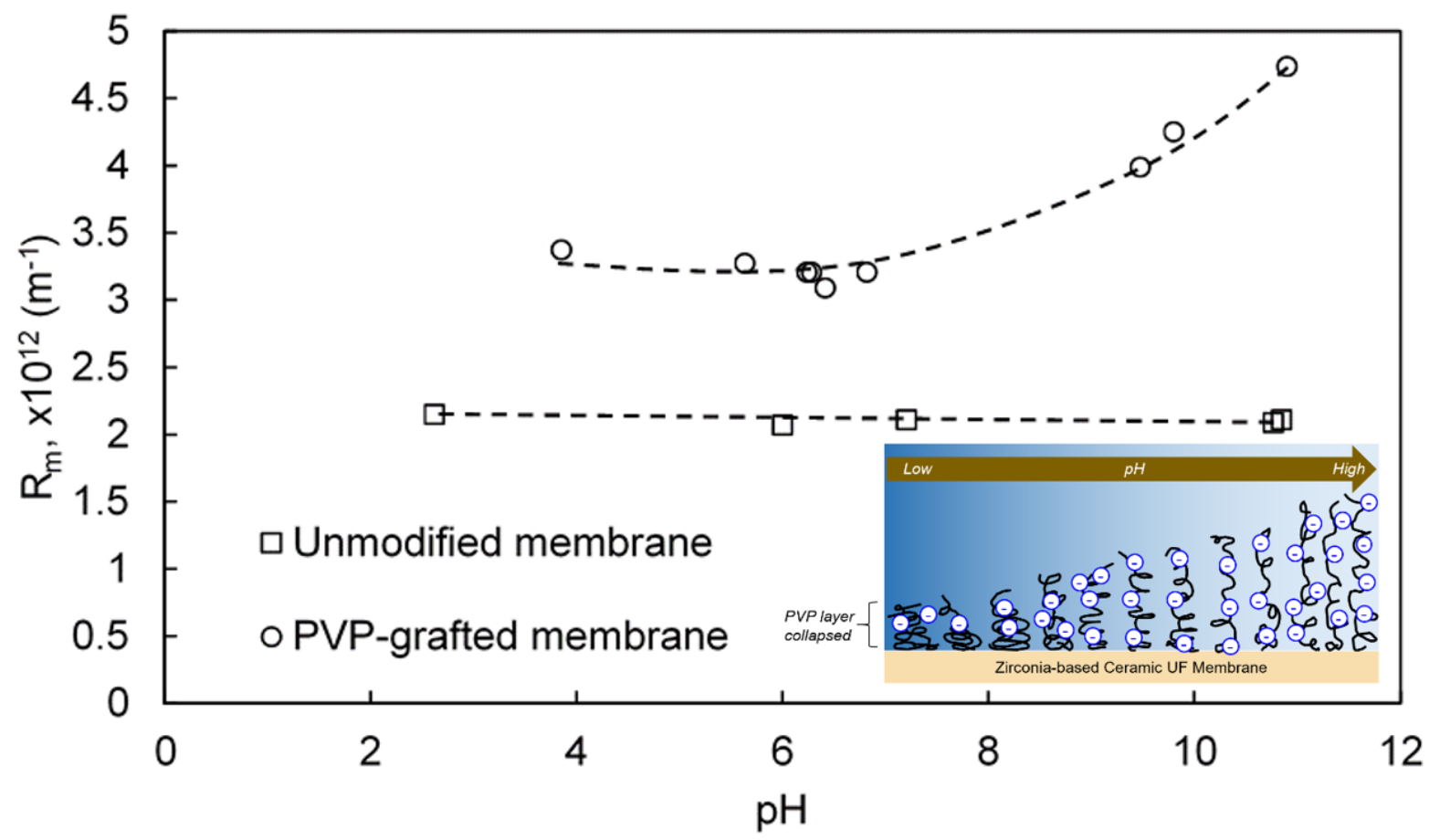

Figure 4. Effect of $\mathrm{pH}$ on unmodified and $\mathrm{PVP}-\mathrm{ZrO}_{2}$ membrane resistance at Ionic strength of $0.1 \mathrm{M}$. (Inset Figure depicts the swelling of the tethered PVP chains upon $\mathrm{pH}$ increase).

The PVP-ZrO $\mathrm{rO}_{2}$ membrane hydraulic resistance, $R_{m}$, did not display a discernible ionic strength dependence (range of $0.001-0.5 \mathrm{M}$ ) for tests at $\mathrm{pH} 7$ (Figure 5), but was a factor of 2.2-2.4 above that of the unmodified membrane. At the above ionic strength range, charge screening by salt ions [26,27] reduces chain-chain or segment-segment repulsion; thus, the tethered PVP chains should be expected to be in a more collapsed conformation [50]. However, a slight hydraulic resistance increase of $\sim 11 \%$ was observed for the unmodified $\mathrm{ZrO}_{2}$ membrane over the above ionic strength range, plausibly due to the diffusion layer compression as reported in the case for alumina membranes [51].

Hydraulic resistance of the PVP- $\mathrm{ZrO}_{2}$ membrane was also evaluated over an ionic strength range reported for the membrane filtration processing of wine (0.01-0.15 M [37]), milk ( 0.08-0.3 M [38,39]), and beer (0.01-0.5 M [40]). With increased membrane permeate flux, one should expect that the tethered layers at pore openings (and possibly within the membrane pores) would offer greater flow resistance due to shear-induced deformation [52]. This was indeed the case as shown in the example provided in Table A1, Appendix A, revealing $\sim 16 \%$ membrane resistance increase (from $2.72 \times 10^{12}$ to $3.15 \times 10^{12} \mathrm{~m}^{-1}$ ) as the permeate flux increased by $\sim 3$-fold. The hydraulic permeability did not vary with the membrane tube-side Reynolds number, over the range of 500-3600, at the solution $\mathrm{pH}$ of 7 . The above behavior suggests that shear-deformation of the tethered chains on the membrane surface (if occurring) did not contribute to pore blockage. 


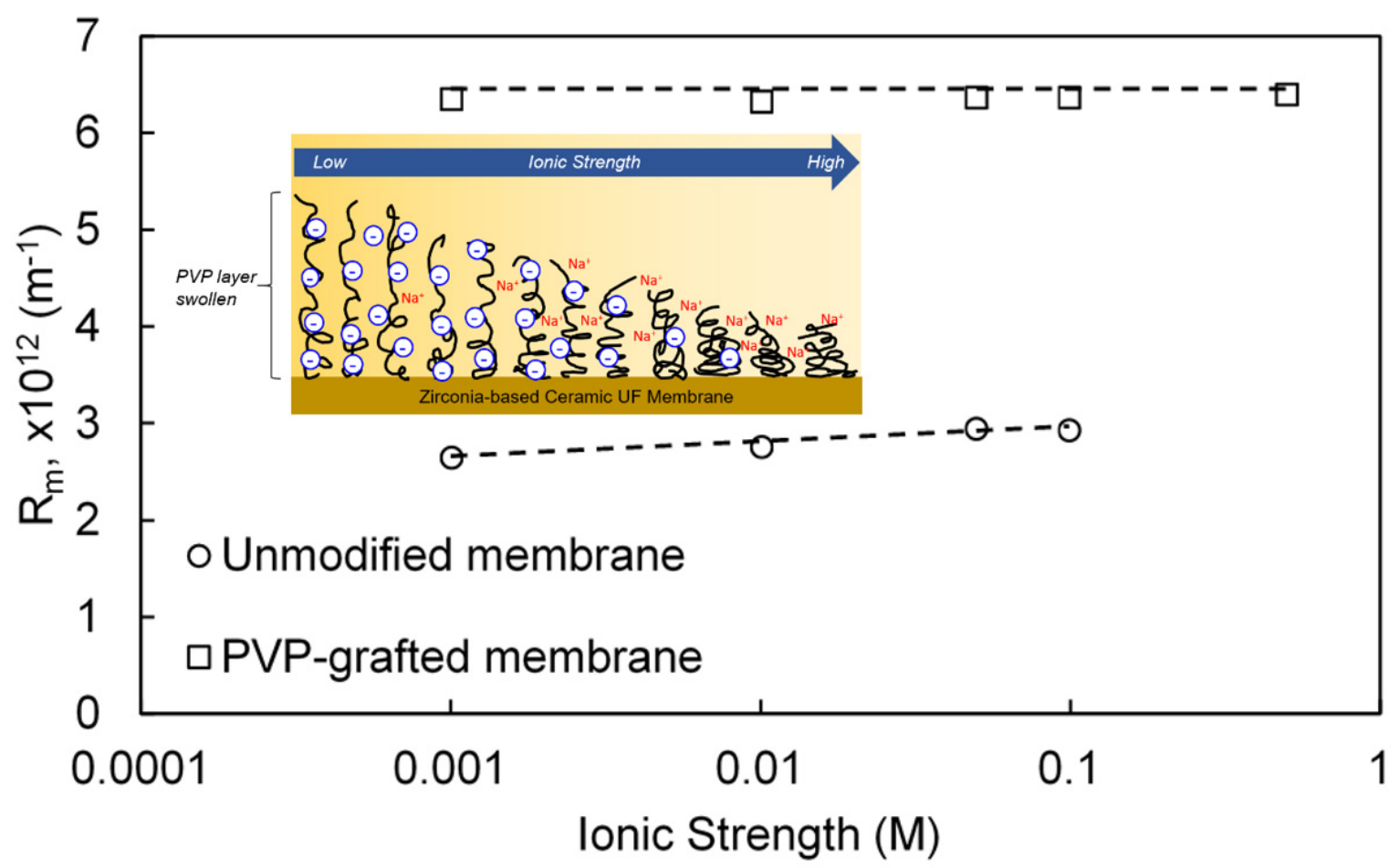

Figure 5. Effect of ionic strength on hydraulic resistance of unmodified and $\mathrm{PVP}-\mathrm{ZrO} \mathrm{r}_{2}$ membranes at $\mathrm{pH}$ of 7. (Inset figure is a depiction of the collapse of the progressive collapse of the tethered chains with increasing ionic strength which leads to the observed rise in membrane hydraulic resistance).

\subsection{Effect of Ionic Strength on PVP-ZrO $\mathrm{Zr}_{2}$ Membrane Protein Fouling}

The hydraulic resistance of the $\mathrm{PVP}-\mathrm{ZrO}_{2}$ membrane was significantly impacted by protein fouling in the filtration of BSA and Lys as assessed from flux decline measurements (Figure A2, Appendix A). Ionic strength had a significant impact on $\mathrm{PVP}-\mathrm{ZrO}_{2}$ membrane water permeability as quantified by the hydraulic membrane resistance imparted by BSA and Lys protein fouling as illustrated in Figure 6 for filtration at $\mathrm{pH}$ 7. Over the ionic strength range of $0.001-0.5 \mathrm{M}$, the total fouling resistance (i.e., cake plus irreversible fouling) for BSA filtration (Figure 6a) increased by $\sim 69 \%$ (from $2.5 \times 10^{12}$ to $4.2 \times 10^{12} \mathrm{~m}^{-1}$ ). Over the same ionic strength, the fouling resistance for Lys filtration was in the range of $2.3 \times 10^{12}-3.1 \times 10^{12} \mathrm{~m}^{-1}$ displaying an apparent minimum at the ionic strength of $\sim 0.1 \mathrm{M}$. For both BSA and Lys filtration, cake (reversible) fouling increased by a factor of $\sim 23$ and $\sim 3$, respectively, as the solution ionic strength increased from 0.001 to $0.5 \mathrm{M}$.

As the ionic strength increases the accompanied electric double compression (or charge screening/shielding effect) weakens the electrostatic protein-protein repulsion [53]; hence, a greater level of multilayer protein buildup should be expected on the membrane surface. At lower ionic strength, the tethered PVP polymer chains are also in a more swollen conformation which: (a) allows tethered chain segment mobility (due to Brownian motion of chain segments); and (b) decreases the effective protein-surface contact (at the brush edge) surface area (Figure 7). Therefore, foulant cake layer buildup on the brush layer should decrease with decreasing ionic strength [49]. 

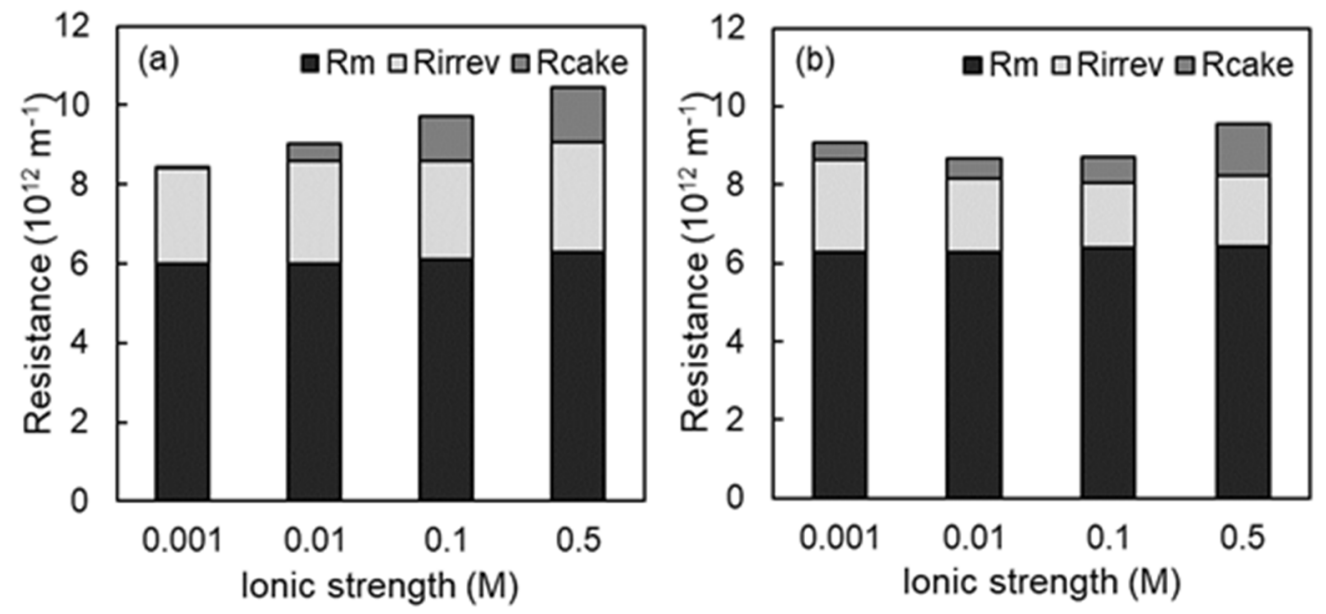

Figure 6. Dependence of membrane fouling resistances $\left(R_{\text {irrev }}\right.$ and $\left.R_{\text {cake }}\right)$ on ionic strength at $\mathrm{pH}$ of 7 for $(\mathbf{a})$ BSA and (b) Lys filtration with PVP-grafted Carbosep M1 membrane. $\left(R_{m}=\right.$ membrane resistance; unmodified membrane irreversible BSA and Lys fouling resistances for the indicated ionic strength range are $4.7-5.3 \times 10^{12} \mathrm{~m}^{-1}$ and $2.8-3.5 \times 10^{12} \mathrm{~m}^{-1}$, respectively).

(a)
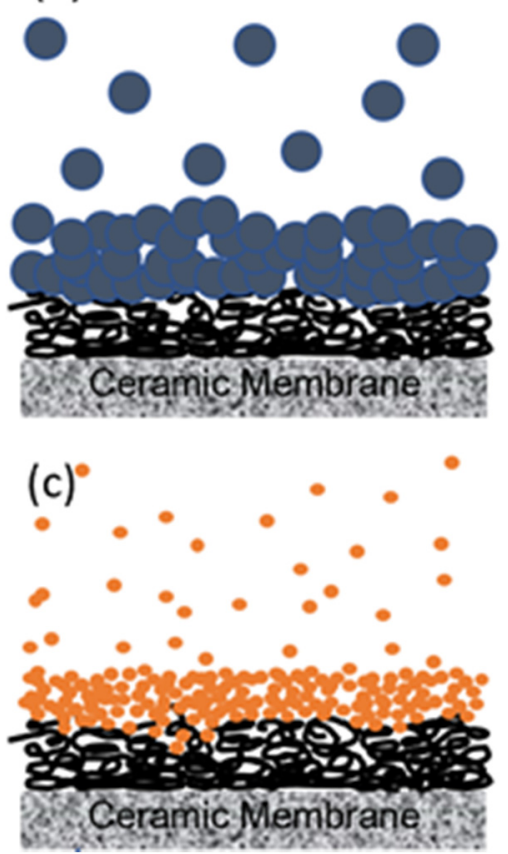

(b)

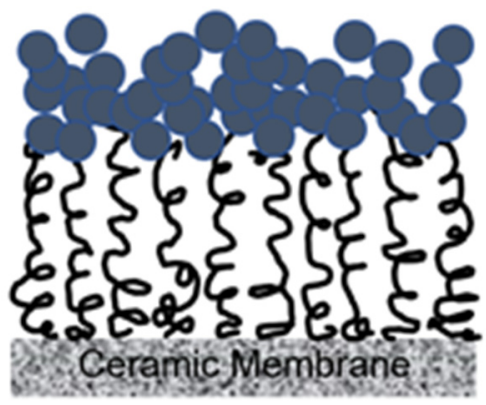

(d) $\bullet \bullet \bullet \bullet$

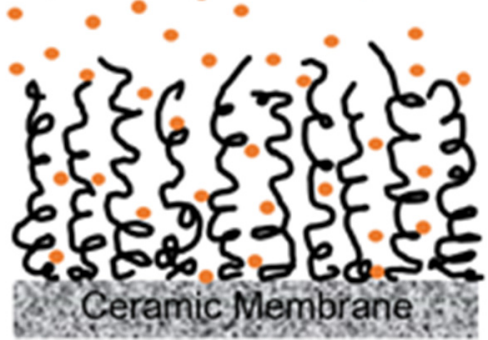

Figure 7. Schematic model illustration of protein fouling with different size foulant molecules at swollen and collapsed tethered polymer layer conformations. (a) Collapsed chains of the tethered layer with multi-layer of strongly adhered foulant molecules (BSA) and (b) tethered layer of swollen chains. (c) Collapsed tethered layer with foulant molecules (Lys) having dimensions smaller than chain-chain separation, and (d) swollen tethered chains where foulant penetration and adsorption onto the underlying membrane active layer can occur.

Irreversible membrane protein fouling is attributed primarily to surface adsorption and pore plugging. Previous work has shown that the adsorption of Lys on $\mathrm{ZrO}_{2}$ surface with tethered PVP chains is significantly lower relative to the native $\mathrm{ZrO}_{2}$ surface [28]. Indeed, irreversible fouling resistances for BSA and Lys for the PVP-Z $\mathrm{rO}_{2}$ membrane were lower by a factor of 1.89-1.96 and 1.21-1.94, respectively, relative to the unmodified $\mathrm{ZrO}_{2}$ membrane (Table A2, Appendix A). The corresponding BSA and Lys irreversible fouling resistances of the unmodified $\mathrm{ZrO}_{2}$ membrane were $(5.10 \pm 0.20) \times 10^{12} \mathrm{~m}^{-1}$ and 
$(3.1 \pm 0.2) \times 10^{12} \mathrm{~m}^{-1}$. Here we note that the tethered PVP chain-chain separation, for the present surface graft polymerization approach, has been previously reported to be in the range of $\sim 30-100 \AA[16,28,54]$. Given the dimensions of BSA $(140 \times 40 \times 40 \AA$ [55]) and Lys (90 A maximum length and $\sim 18 \AA$ equatorial diameter [56]), the tethered chainchain separation distance could govern the difference in irreversible fouling between these proteins. Therefore, it is reasonable to suggest that, unlike BSA, the lower membrane rejection of Lys molecules (Table 2) enabled Lys migration, through the tethered PVP layer, to the underlying membrane pores (Figure 7), thus leading to increased propensity for Lys pore surface adsorption and plugging. It is also noted that at $\mathrm{pH} 7$ the $\mathrm{PVP}-\mathrm{ZrO}_{2}$ surface exhibits a slight negative charge [28], while Lys [57] and BSA [58] are positively and negatively charged, respectively. Increasing ionic strength also leads to charge shielding for both proteins, as well as the PVP- $\mathrm{ZrO}_{2}$ surface. Therefore, at a lower ionic strength, stronger attractions are expected among Lys molecules and the $\mathrm{PVP}-\mathrm{ZrO}_{2}$ membrane surface relative to the stronger BSA-surface repulsion, hence the higher observed irreversible fouling resistance than for the unmodified $\mathrm{ZrO}_{2}$ membrane for Lys relative to BSA.

Table 2. Membrane protein rejection at the end of filtration for BSA and Lys of PVP- $\mathrm{ZrO}_{2}$ membrane at the tested range of ionic strength ${ }^{(a)}$.

\begin{tabular}{ccc}
\hline Ionic Strength (M) & BSA Rejection (\%) & Lys Rejection (\%) \\
\hline 0.001 & 93.2 & 39.9 \\
0.01 & 78.5 & 4.6 \\
0.1 & 49.1 & 2.6 \\
0.5 & 56.3 & 5.8 \\
\hline
\end{tabular}

(a) Protein rejection was determined at $\mathrm{pH}=7$.

Rejections of BSA and Lys by the PVP- $\mathrm{ZrO}_{2}$ membrane were determined, just prior to the filtration period termination, over the tested range of ionic strength to further assess the impact of the tethered PVP layer (Table 2). BSA and Lys rejections, within the level of measurement discrimination, were substantially higher at the lower ionic strengths. As the ionic strength increased from $0.001 \mathrm{M}$ to $0.5 \mathrm{M}$, BSA rejection decreased from about $93 \%$ to $56 \%$, while that of Lys decreased from $58 \%$ to $6 \%$. Given that the PVP-ZrO 2 membrane hydraulic resistance was invariant with respect to ionic strength, it is reasonable to assume that the membrane pore size was unaltered over the ionic strength range of $0.001-0.5 \mathrm{M}$. As the solution ionic strength decreases, protein-protein repulsion will increase owing to weaker charge screening. Thus, the cake layer presence on the membrane surface in the filtration of both proteins (Figure 6) should increase protein rejection [59]).

\subsection{Impact of $\mathrm{pH}$ on $\mathrm{PVP}-\mathrm{ZrO}_{2}$ Membrane Protein Fouling}

Assessment of the impact of $\mathrm{pH}$ on protein fouling (Figure 8) was carried out at high ionic strength at which a high degree of fouling was expected due to charge screening of both the protein molecules and the PVP tethered layer. The total fouling resistance (i.e., reversible plus irreversible fouling resistances) was greatest for BSA and Lys $\left(6.6 \times 10^{12}\right.$ and $1.1 \times 10^{13} \mathrm{~m}^{-1}$ ) at $\mathrm{pH}$ levels of 4.8 and 10 (Figure $8 \mathrm{a}, \mathrm{b}$ ), respectively. It is noted that the above $\mathrm{pH}$ levels were at or in proximity to their corresponding isoelectric point (IEP) values of 4.8 [58] and 10.7 [57]. The repulsion between protein molecules is minimized at IEP, improving the buildup of a protein deposition layer on top of the fouled membrane. The irreversible membrane fouling resistances for BSA and Lys at and in proximity to their $\operatorname{IEP}\left(6.5 \times 10^{12}\right.$ and $\left.4.7 \times 10^{12} \mathrm{~m}^{-1}\right)$, respectively, is noted, comprising about $98.5 \%$ and $42 \%$ of the total fouling resistance. At the above $\mathrm{pH}$ levels, irreversible fouling resistances for BSA and Lys were about $10 \%$ and $48 \%$ lower for the PVP- $\mathrm{ZrO}_{2}$ membrane (Table A2, Appendix A) relative to the unmodified $\mathrm{ZrO}_{2}$ membrane. The above behavior can be rationalized noting that the BSA molecules at their IEP $(\mathrm{pH}=4.8)$ are at approximately neutral charge; thus, surface-protein and protein-protein electrostatic repulsion was not a dominant interaction force. Given the above, it is argued that the relatively small (10\%) ir- 
reversible fouling resistance reduction is likely to be due to the screening of the underlying membrane surface by the PVP brush layer.
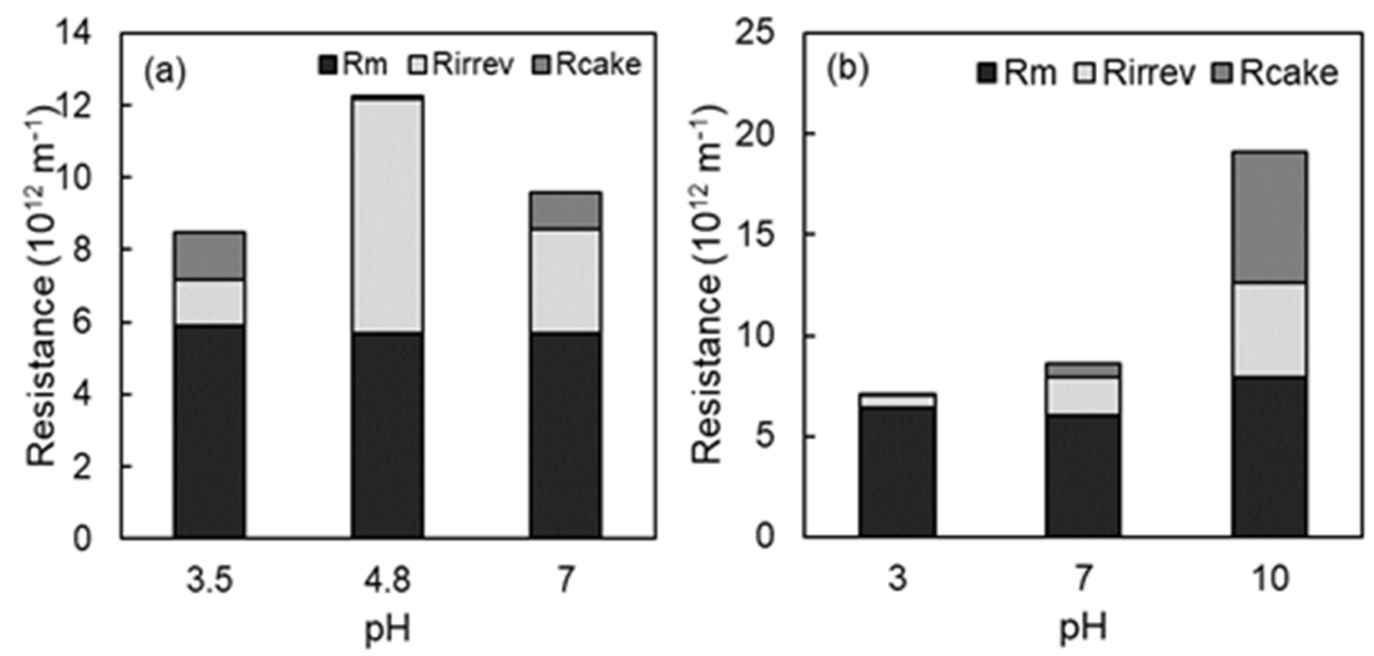

Figure 8. Effect of $\mathrm{pH}$ on PVP-ZrO $\mathrm{Zr}_{2}$ membrane fouling resistances $\left(R_{\text {cake }}\right.$ and $\left.R_{\text {irrev }}\right)$ filtration of (a) BSA and (b) Lys solutions at the ionic strength of $0.1 \mathrm{M}\left(R_{m}\right.$-membrane resistance).

In contrast, Lys molecules were slightly positively charged at $\mathrm{pH}=10$, in proximity to the IEP for Lys. Therefore, electrostatic attraction of Lys to both the negatively charged PVP- $\mathrm{ZrO}_{2}$ and unmodified $\mathrm{ZrO}_{2}$ membranes should be expected at the above condition. Here we note that the significant reduction in irreversible fouling resistance for Lys at $\mathrm{pH}$ $=10$ (Table A2, Appendix A), relative to the unmodified $\mathrm{ZrO}_{2}$ membrane, is not surprising. In addition to tethered PVP screening of the underlying $\mathrm{ZrO}_{2}$ membrane, at the above $\mathrm{pH}$, the negative surface charge of the $\mathrm{ZrO}_{2}$ membrane was lower by a factor of $\sim 2.8$ relative to the PVP- $\mathrm{ZrO}_{2}$ membrane [28]. Therefore, stronger electrostatic attraction should be expected at the above $\mathrm{pH}$ between Lys molecules and the unmodified $\mathrm{ZrO}_{2}$ membrane surface relative to the $\mathrm{PVP}-\mathrm{ZrO}_{2}$ membrane surface.

The lowest level of reversible membrane fouling resistance was observed at the IEP of BSA. The above result is linked to the aggregation of BSA molecules [60] at the IEP and their deposition and adsorption onto the PVP- $\mathrm{ZrO}_{2}$ membrane surface [61]. BSA aggregates possess strong intermolecular attractions and thus a cake layer of BSA aggregates can be difficult to remove. Indeed, as shown in Figure $8 \mathrm{a}$, only $~ 1.5 \%$ of the total BSA fouling resistance is attributed to reversible fouling at $\mathrm{pH}=4.8$. In contrast, for Lys the highest reversible fouling occurred at $\mathrm{pH} 10$ which is in proximity of its IEP of 10.7). At and near its IEP, partial breakdown of the globular Lys structure is likely to result in the formation of a layer of unfolded, loose structure of denatured Lys [62] on top of the membrane surface. Therefore, the formed Lys cake layer should be removable at greater ease relative to BSA via D.I. water cleaning. As a result, upon increasing the $\mathrm{pH}$ from 3 to 10, the overall fouling resistance for Lys filtration increased accounting for $10 \%$ to $58 \%$ of the total filtration resistance. Correspondingly, the reversible cake fouling resistance also increased comprising $13 \%-58 \%$ of the total fouling resistance (Figure $8 b$ ).

Protein rejection for $\mathrm{BSA}$, determined at the filtration period end over a $\mathrm{pH}$ range of 3.5-7, was highest (99.7\%) at the BSA IEP of 4.8 , but declined to $84 \%$ and $48 \%$ at the lower $\mathrm{pH}$ values of 3.5 and 7 , respectively (Table 3). The higher rejection of BSA at the IEP is attributed to the tendency of BSA molecules to aggregate as the $\mathrm{pH}$ tends toward the IEP [60]. It is noted that as the IEP of Lys is approached, partial breakdown of the globular Lys structure [62] should lead to lower rejection (i.e., greater passage) of Lys through the membrane. Indeed, as observed in the present study, the rejection of Lys decreased from about $25 \%$ to $0.5 \%$ as the $\mathrm{pH}$ increased from 3 to 10 (near the Lys IEP of 10.7). It is emphasized that the above trend of protein rejection dependence on $\mathrm{pH}$ was contrary 
to the observed increased hydraulic resistance of the PVP- $\mathrm{ZrO}_{2}$ membrane (Figure 4). This behavior suggests that the effective pore size decreases with $\mathrm{pH}$ rise thus leading to correspondingly higher protein rejection at elevated $\mathrm{pH}$. It appears, however, that proteinprotein aggregation and disaggregation were likely to have been more significant, relative to any conformational changes of the tethered PVP, in determining rejection for the present membranes and selected model proteins.

Table 3. Membrane protein rejection at the end of filtration for BSA and Lys of $\mathrm{PVP}-\mathrm{ZrO}_{2}$ membrane at the tested range of $\mathrm{pH}^{(\mathrm{a})}$.

\begin{tabular}{ccc}
\hline $\mathbf{p H}$ & Protein & Rejection (\%) \\
\hline 3.5 & BSA & 84.2 \\
4.8 & BSA & 99.7 \\
7 & BSA & 48.4 \\
\hline 3 & Lys & 24.4 \\
7 & Lys & 4.3 \\
10 & Lys & 0.5 \\
\hline
\end{tabular}

(a) Protein rejection was determined at ionic strength of $0.1 \mathrm{M}$.

\section{Conclusions}

The impact of a tethered PVP surface layer on the hydraulic resistance of ultrafiltration zirconia $\left(\mathrm{ZrO}_{2}\right)$ membrane was evaluated over $\mathrm{pH}$ and ionic strength ranges of $4-11$ and 0.001-1 M, respectively, and for filtration of BSA and Lys as model proteins. The hydraulic resistance of the PVP surface-modified $\mathrm{ZrO}_{2}$ membrane $\left(\mathrm{PVP}-\mathrm{ZrO}_{2}\right)$ demonstrated a significant rise by $\sim 48 \%$ upon $\mathrm{pH}$ increases from 6 to 11, but remained essentially unaltered over the above ionic strength range. The above behavior was attributed to $\mathrm{pH}$-triggered responsive conformational change (i.e., swelling/collapse) of the tethered PVP brush. Filtration of both BSA and Lys was accompanied by increased reversible (cake) fouling resistance as the solution ionic strength increased from 0.001 to $0.5 \mathrm{M}$. The above behavior was attributed to weakening electrostatic protein-protein repulsion with increased ionic strength, and hence a greater potential for multilayer protein buildup on the membrane surface. Irreversible fouling in BSA and Lys filtration for the PVP- $\mathrm{ZrO}_{2}$ membrane was significantly lower, by $11-49 \%$ and $18-74 \%$, respectively, relative to the unmodified membrane over the investigated $\mathrm{pH}$ and ionic ranges of 3-10 and $0.001-0.5 \mathrm{M}$, respectively. Under conditions of tethered chains swelling (i.e., low ionic strength and high $\mathrm{pH}$ ), irreversible fouling reduction may be attributed to partial chain segments Brownian motion mobility and decreased effective contact area for protein-brush layer interactions.

Author Contributions: Project conceptualization, supervision, resources, writing, funding acquisition, and supervision are attributed to Y.C. (Yoram Cohen). Data analysis and manuscript preparation was carried out by Y.C. (Yian Chen) and Y.C. (Yoram Cohen). The experimental portion of the study was carried out by M.R.-B. with additional supervision by F.G. All authors have read and agreed to the published version of the manuscript.

Funding: This research received no external funding.

Institutional Review Board Statement: Not applicable.

Informed Consent Statement: Not applicable.

Data Availability Statement: The data presented in this study are available in this article.

Conflicts of Interest: The authors declare no conflict of interest. 


\section{Appendix A}

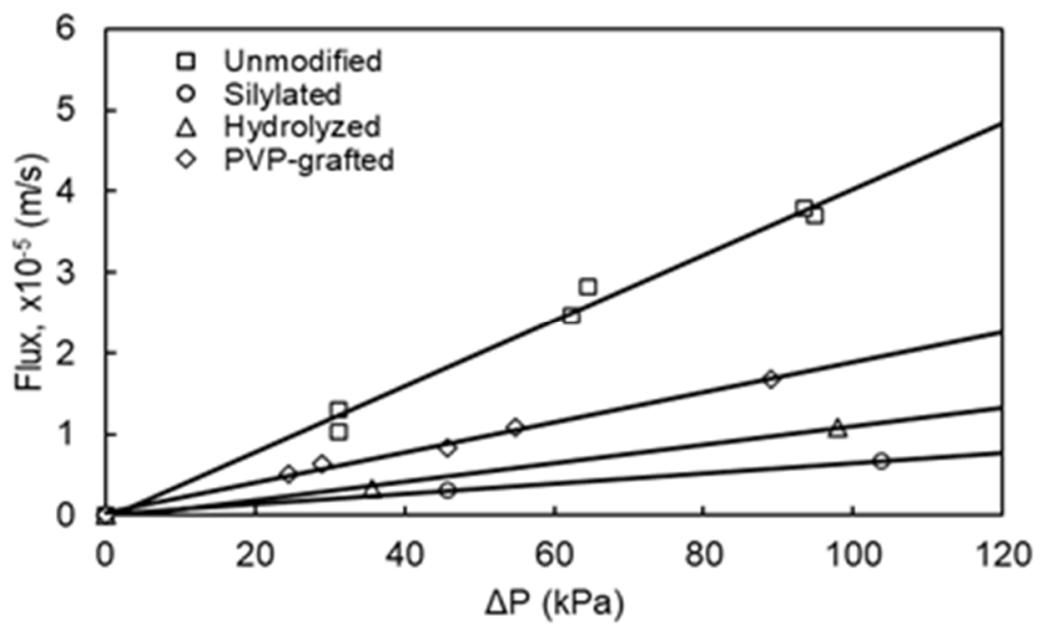

Figure A1. Permeate flux dependence on transmembrane pressure for the unmodified, silylated, hydrolyzed, and PVP-grafted membranes $\left(R^{2}>0.98\right.$ for the linear plots). The measurements were at a tube-side Reynolds number of 3600 .

Table A1. Effect of Reynolds number (Re) on hydraulic resistance of PVP-grafted membranes for two different transmembrane pressures, 30 and $100 \mathrm{kPa}$ (corresponding permeate flux of $6.4 \times 10^{-4}$ and $1.9 \times 10^{-5} \mathrm{~m} / \mathrm{s}$ determined for D.I. water at $\mathrm{pH} 7$ ). The unmodified membrane resistance was $\sim 2.1 \times 10^{-12} \mathrm{~m}^{-1}$ at $100 \mathrm{kPa}$.

\begin{tabular}{ccc}
\hline $\boldsymbol{\Delta P} \mathbf{( k P a )}$ & $\mathbf{R e}$ & $\mathbf{R}_{\mathbf{m}}, \times \mathbf{1 0}^{\mathbf{1 2}} \mathbf{~ m}^{\mathbf{- 1}}$ \\
\hline 30 & 1187 & 2.79 \\
30 & 1818 & 2.66 \\
30 & 3724 & 2.72 \\
100 & 743 & 3.09 \\
100 & 1822 & 3.15 \\
100 & 2804 & 3.20 \\
100 & 3724 & 3.17 \\
\hline
\end{tabular}

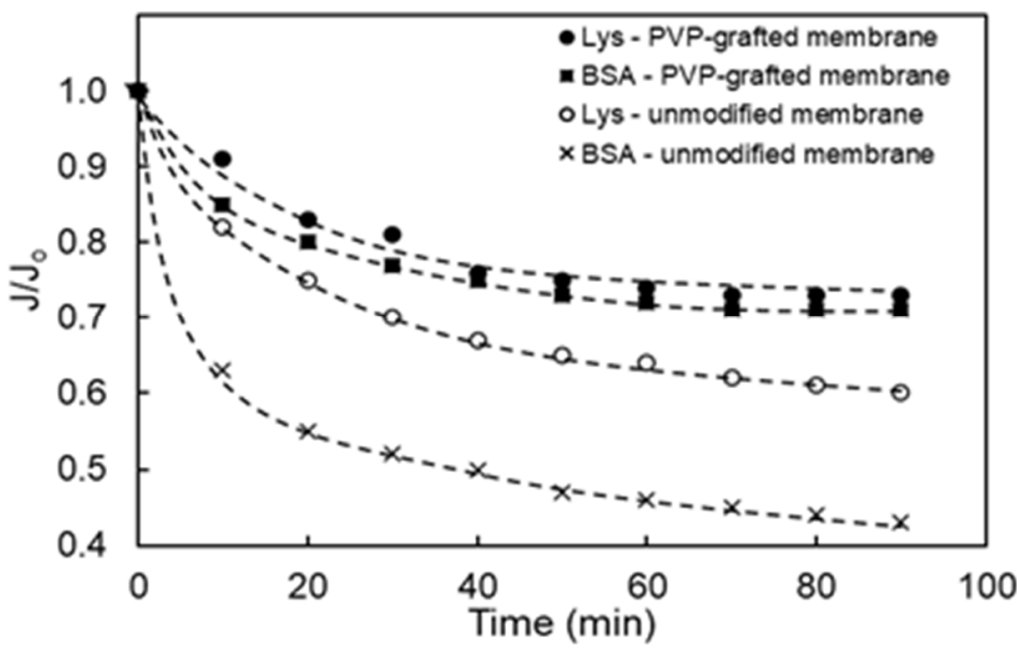

Figure A2. Flux decline curves for the unmodified Carbosep M1 and $\mathrm{PVP}-\mathrm{ZrO}_{2}$ membranes filtration of BSA and Lys solutions in terms of the normalized flux decline with unmodified and $\mathrm{PVP}-\mathrm{ZrO}_{2}$ Carbosep M1 membranes at ionic strength of $0.1 \mathrm{M} \mathrm{NaCl}$ and $\mathrm{pH}$ of 7. 
Table A2. Summary of irreversible fouling resistance for unmodified and PVP-tethered Zirconia membranes.

\begin{tabular}{|c|c|c|c|c|}
\hline Foulant & $\mathrm{pH}$ & Ionic Strength (M) & $\begin{array}{l}\text { Unmodified Membrane } R_{\text {irrev }} \\
\qquad\left(\times 10^{12} \mathrm{~m}^{-1}\right)\end{array}$ & $\begin{array}{c}\text { PVP-ZrO }_{2} \text { Membrane } \mathrm{R}_{\text {irrev }} \\
\left(\times 10^{12} \mathrm{~m}^{-1}\right)\end{array}$ \\
\hline \multirow{6}{*}{ Lys } & 3 & 0.1 & 2.3 & 0.6 \\
\hline & 7 & 0.1 & 3.7 & 1.9 \\
\hline & 10 & 0.1 & 4.1 & 4.7 \\
\hline & 7 & 0.001 & 2.8 & 2.3 \\
\hline & 7 & 0.01 & 3.0 & 1.9 \\
\hline & 7 & 0.5 & 3.5 & 1.8 \\
\hline \multirow{6}{*}{ BSA } & 3.5 & 0.1 & 1.7 & 1.3 \\
\hline & 4.8 & 0.1 & 7.3 & 6.5 \\
\hline & 7 & 0.1 & 5.3 & 2.7 \\
\hline & 7 & 0.001 & 4.7 & 2.4 \\
\hline & 7 & 0.01 & 5.1 & 2.6 \\
\hline & 7 & 0.5 & 5.3 & 2.8 \\
\hline
\end{tabular}

\section{References}

1. Samaei, S.M.; Gato-Trinidad, S.; Altaee, A. The application of pressure-driven ceramic membrane technology for the treatment of industrial wastewaters-A review. Sep. Purif. Technol. 2018, 200, 198-220. [CrossRef]

2. Amin, S.K.; Abdallah, H.A.M.; Roushdy, M.H.; El-Sherbiny, S.A. An overview of production and development of ceramic membranes. Int. J. Appl. Eng. Res. 2016, 11, 7708-7721.

3. He, Z.; Lyu, Z.; Gu, Q.; Zhang, L.; Wang, J. Ceramic-based membranes for water and wastewater treatment. Colloids Surf. A Physicochem. Eng. Asp. 2019, 578, 123513. [CrossRef]

4. Membrane Separation Materials Market Research Report—Global Forecast Till 2023; Market Research Future (MRFR): Maharashtra, India, 2019.

5. Yue, X.; Koh, Y.K.K.; Ng, H.Y. Effects of dissolved organic matters (DOMs) on membrane fouling in anaerobic ceramic membrane bioreactors (AnCMBRs) treating domestic wastewater. Water Res. 2015, 86, 96-107. [CrossRef]

6. Tang, S.; Zhang, Z.; Liu, J.; Zhang, X. Double-win effects of in-situ ozonation on improved filterability of mixed liquor and ceramic UF membrane fouling mitigation in wastewater treatment? J. Membr. Sci. 2017, 533, 112-120. [CrossRef]

7. Tang, S.; Zhang, Z.; Zhang, X. Coupling in-situ ozonation with ferric chloride addition for ceramic ultrafiltration membrane fouling mitigation in wastewater treatment: Quantitative fouling analysis. J. Membr. Sci. 2018, 555, 307-317. [CrossRef]

8. Laîné, J.-M.; Campos, C.; Baudin, I.; Janex, M.-L. Understanding membrane fouling: A review of over a decade of research. Water Supply 2003, 3, 155-164. [CrossRef]

9. Biron, D.D.S.; Dos Santos, V.; Zeni, M. Ceramic Membranes Applied in Separation Processes; Metzler, J.B., Ed.; Springer: New York, NY, USA, 2018.

10. Guo, W.; Ngo, H.-H.; Li, J. A mini-review on membrane fouling. Bioresour. Technol. 2012, 122, 27-34. [CrossRef] [PubMed]

11. Gao, W.; Liang, H.; Ma, J.; Han, M.; Chen, Z.-L.; Han, Z.-S.; Li, G.-B. Membrane fouling control in ultrafiltration technology for drinking water production: A review. Desalination 2011, 272, 1-8. [CrossRef]

12. Ambrosi, A.; Cardozo, N.S.M.; Tessaro, I.C. Membrane Separation Processes for the Beer Industry: A Review and State of the Art. Food Bioprocess. Technol. 2014, 7, 921-936. [CrossRef]

13. Kumar, P.; Sharma, N.; Ranjan, R.; Kumar, S.; Bhat, Z.F.; Jeong, D.K. Perspective of Membrane Technology in Dairy Industry: A Review. Asian-Australas. J. Anim. Sci. 2013, 26, 1347-1358. [CrossRef]

14. El Rayess, Y.; Albasi, C.; Bacchin, P.; Taillandier, P.; Mietton-Peuchot, M.; Devatine, A. Analysis of membrane fouling during cross-flow microfiltration of wine. Innov. Food Sci. Emerg. Technol. 2012, 16, 398-408. [CrossRef]

15. Zhou, S.; Xue, A.; Zhao, Y.; Li, M.; Wang, H.; Xing, W. Grafting polyacrylic acid brushes onto zirconia membranes: Fouling reduction and easy-cleaning properties. Sep. Purif. Technol. 2013, 114, 53-63. [CrossRef]

16. Faibish, R.S.; Cohen, Y. Fouling-resistant ceramic-supported polymer membranes for ultrafiltration of oil-in-water microemulsions. J. Membr. Sci. 2001, 185, 129-143. [CrossRef]

17. Malik, A.A.; Kour, H.; Bhat, A.; Kaul, R.K.; Khan, S.; Khan, S.U. Commercial utilization of membranes in food industry. Int. J. Food Nutr. Saf. 2013, 3, 147-170.

18. Zhou, S.; Xue, A.; Zhang, Y.; Li, M.; Wang, J.; Zhao, Y.; Xing, W. Fabrication of temperature-responsive ZrO2 tubular membranes, grafted with poly (N-isopropylacrylamide) brush chains, for protein removal and easy cleaning. J. Membr. Sci. 2014, 450, 351-361. [CrossRef]

19. Zhao, Y.; Zhou, S.; Li, M.; Xue, A.; Zhang, Y.; Wang, J.; Xing, W. Humic acid removal and easy-cleanability using temperatureresponsive $\mathrm{ZrO} 2$ tubular membranes grafted with poly(N-isopropylacrylamide) brush chains. Water Res. 2013, 47, $2375-2386$. [CrossRef] [PubMed]

20. Banerjee, I.; Pangule, R.C.; Kane, R.S. Antifouling Coatings: Recent Developments in the Design of Surfaces That Prevent Fouling by Proteins, Bacteria, and Marine Organisms. Adv. Mater. 2010, 23, 690-718. [CrossRef] 
21. Mustafa, G.; Wyns, K.; Vandezande, P.; Buekenhoudt, A.; Meynen, V. Novel grafting method efficiently decreases irreversible fouling of ceramic nanofiltration membranes. J. Membr. Sci. 2014, 470, 369-377. [CrossRef]

22. Iv, J.J.K.; Imbrogno, J.; Belfort, G. Polymer Brushes for Membrane Separations: A Review. ACS Appl. Mater. Interfaces 2016, 8, 28383-28399. [CrossRef]

23. Ismail, N.; Salleh, W.; Ismail, A.; Hasbullah, H.; Yusof, N.; Aziz, F.; Jaafar, J. Hydrophilic polymer-based membrane for oily wastewater treatment: A review. Sep. Purif. Technol. 2020, 233, 116007. [CrossRef]

24. Kim, S.; Cohen, Y. Surface Modified Reverse Osmosis Membranes. In Advances in Water Desalination Technologies; Cohen, Y., Ed.; World Scientific: Hackensack, NJ, USA, 2021.

25. Wandera, D.; Wickramasinghe, S.R.; Husson, S.M. Stimuli-responsive membranes. J. Membr. Sci. 2010, 357, 6-35. [CrossRef]

26. Darvishmanesh, S.; Qian, X.; Wickramasinghe, S.R. Responsive membranes for advanced separations. Curr. Opin. Chem. Eng. 2015, 8, 98-104. [CrossRef]

27. Zhang, X.; Tian, J.; Gao, S.; Shi, W.; Zhang, Z.; Cui, F.; Zhang, S.; Guo, S.; Yang, X.; Xie, H.; et al. Surface functionalization of TFC FO membranes with zwitterionic polymers: Improvement of antifouling and salt-responsive cleaning properties. J. Membr. Sci. 2017, 544, 368-377. [CrossRef]

28. Rovira-Bru, M.; Giralt, F.; Cohen, Y. Protein Adsorption onto Zirconia Modified with Terminally Grafted Polyvinylpyrrolidone. J. Colloid Interface Sci. 2001, 235, 70-79. [CrossRef]

29. Faibish, R.S.; Cohen, Y. Fouling and rejection behavior of ceramic and polymer-modified ceramic membranes for ultrafiltration of oil-in-water emulsions and microemulsions. Colloids Surfaces A Physicochem. Eng. Asp. 2001, 191, 27-40. [CrossRef]

30. Chang, X.; Wang, Z.; Quan, S.; Xu, Y.; Jiang, Z.; Shao, L. Exploring the synergetic effects of graphene oxide (GO) and polyvinylpyrrodione (PVP) on poly(vinylylidenefluoride) (PVDF) ultrafiltration membrane performance. Appl. Surf. Sci. 2014, 316, 537-548. [CrossRef]

31. Chaimberg, M.; Parnas, R.; Cohen, Y. Graft polymerization of polyvinylpyrrolidone onto silica. J. Appl. Polym. Sci. 1989, 37, 2921-2931. [CrossRef]

32. Pachova, V.; Ferrando, M.; Guell, C.; Lóapez, F. Protein Adsorption onto Metal Oxide Materials in White Wine Model Systems. J. Food Sci. 2002, 67, 2118-2121. [CrossRef]

33. Jaspe, J.; Hagen, S.J. Do Protein Molecules Unfold in a Simple Shear Flow? Biophys. J. 2006, 91, 3415-3424. [CrossRef] [PubMed]

34. El Rayess, Y.; Mietton-Peuchot, M. Membrane Technologies in Wine Industry: An Overview. Crit. Rev. Food Sci. Nutr. 2015, 56, 2005-2020. [CrossRef]

35. Daufin, G.; Escudier, J.-P.; Carrère, H.; Bérot, S.; Fillaudeau, L.; Decloux, M. Recent and Emerging Applications of Membrane Processes in the Food and Dairy Industry. Food Bioprod. Process. 2001, 79, 89-102. [CrossRef]

36. Braeken, L.; Van Der Bruggen, B.; Vandecasteele, C. Regeneration of brewery waste water using nanofiltration. Water Res. 2004, 38, 3075-3082. [CrossRef]

37. Dufrechou, M.; Poncet-Legrand, C.; Sauvage, F.-X.; Vernhet, A. Stability of White Wine Proteins: Combined Effect of pH, Ionic Strength, and Temperature on Their Aggregation. J. Agric. Food Chem. 2012, 60, 1308-1319. [CrossRef] [PubMed]

38. Jimenez-Lopez, A.; Leconte, N.; Garnier-Lambrouin, F.; Bouchoux, A.; Rousseau, F.; Gésan-Guiziou, G. Ionic strength dependence of skimmed milk microfiltration: Relations between filtration performance, deposit layer characteristics and colloidal properties of casein micelles. J. Membr. Sci. 2011, 369, 404-413. [CrossRef]

39. Nokdbo, R. The concentration of ionized magnesium and calcium in milk. J. Biol. Chem. 1939, 128, 745-757.

40. Lin, H.; Gao, W.; Meng, F.; Liao, B.-Q.; Leung, K.-T.; Zhao, L.; Chen, J.; Hong, H. Membrane Bioreactors for Industrial Wastewater Treatment: A Critical Review. Crit. Rev. Environ. Sci. Technol. 2012, 42, 677-740. [CrossRef]

41. Chew, C.M.; Aroua, M.; Hussain, M. A practical hybrid modelling approach for the prediction of potential fouling parameters in ultrafiltration membrane water treatment plant. J. Ind. Eng. Chem. 2017, 45, 145-155. [CrossRef]

42. Chakrabarty, B.; Ghoshal, A.; Purkait, M. SEM analysis and gas permeability test to characterize polysulfone membrane prepared with polyethylene glycol as additive. J. Colloid Interface Sci. 2008, 320, 245-253. [CrossRef] [PubMed]

43. Tian, J.-Y.; Ernst, M.; Cui, F.; Jekel, M. Effect of particle size and concentration on the synergistic UF membrane fouling by particles and NOM fractions. J. Membr. Sci. 2013, 446, 1-9. [CrossRef]

44. Li, D.; Yao, J.; Liu, B.; Sun, H.; Van Agtmaal, S.; Feng, C. Preparation and characterization of surface grafting polymer of ZrO2 membrane and ZrO2 powder. Appl. Surf. Sci. 2019, 471, 394-402. [CrossRef]

45. Xu, F.; Wei, M.; Zhang, X.; Song, Y.; Zhou, W.; Wang, Y. How Pore Hydrophilicity Influences Water Permeability? Research 2019, 2019, 2581241. [CrossRef] [PubMed]

46. Faibish, R.S.; Yoshida, W.; Cohen, Y. Contact Angle Study on Polymer-Grafted Silicon Wafers. J. Colloid Interface Sci. 2002, 256, 341-350. [CrossRef]

47. Artigas, J. Development of a multiparametric analyser based on ISFET sensors applied to process control in the wine industry. Sens. Actuators B Chem. 2003, 89, 199-204. [CrossRef]

48. Tokareva, I.; Minko, S.; Fendler, A.J.H.; Hutter, E. Nanosensors Based on Responsive Polymer Brushes and Gold Nanoparticle Enhanced Transmission Surface Plasmon Resonance Spectroscopy. J. Am. Chem. Soc. 2004, 126, 15950-15951. [CrossRef]

49. Liu, Z.; Wang, W.; Xie, R.; Ju, X.-J.; Chu, L.-Y. Stimuli-responsive smart gating membranes. Chem. Soc. Rev. 2016, 45, 460-475. [CrossRef] 
50. Drechsler, A.; Elmahdy, M.M.; Uhlmann, P.; Stamm, M. pH and Salt Response of Mixed Brushes Made of Oppositely Charged Polyelectrolytes Studied by in Situ AFM Force Measurements and Imaging. Langmuir 2018, 34, 4739-4749. [CrossRef]

51. Nazzal, F.F.; Wiesner, M.R. pH and ionic strength effects on the performance of ceramic membranes in water filtration. J. Membr. Sci. 1994, 93, 91-103. [CrossRef]

52. Castro, R.P.; Monbouquette, H.G.; Cohen, Y. Shear-induced permeability changes in a polymer grafted silica membrane. J. Membr. Sci. 2000, 179, 207-220. [CrossRef]

53. Miao, R.; Wang, L.; Zhu, M.; Deng, D.; Li, S.; Wang, J.; Liu, T.; Lv, Y. Effect of Hydration Forces on Protein Fouling of Ultrafiltration Membranes: The Role of Protein Charge, Hydrated Ion Species, and Membrane Hydrophilicity. Environ. Sci. Technol. 2016, 51,167-174. [CrossRef]

54. Cohen, Y.; Eisenberg, P.; Chaimberg, M. Permeability of graft-polymerized polyvinylpyrrolidone-silica resin in packed columns. J. Colloid Interface Sci. 1992, 148, 579-586. [CrossRef]

55. Nguyen, T.P.B.; Lee, J.-W.; Shim, W.G.; Moon, H. Synthesis of functionalized SBA-15 with ordered large pore size and its adsorption properties of BSA. Microporous Mesoporous Mater. 2008, 110, 560-569. [CrossRef]

56. Colvin, J.R. The Size and Shape of Lysozyme. Can. J. Chem. 1952, 30, 831-834. [CrossRef]

57. Xu, J.; Wang, Z.; Wang, J.; Wang, S. Positively charged aromatic polyamide reverse osmosis membrane with high anti-fouling property prepared by polyethylenimine grafting. Desalination 2015, 365, 398-406. [CrossRef]

58. Nakamura, K.; Matsumoto, K. Properties of protein adsorption onto pore surface during microfiltration: Effects of solution environment and membrane hydrophobicity. J. Membr. Sci. 2006, 280, 363-374. [CrossRef]

59. She, Q.; Tang, C.Y.; Wang, Y.-N.; Zhang, Z. The role of hydrodynamic conditions and solution chemistry on protein fouling during ultrafiltration. Desalination 2009, 249, 1079-1087. [CrossRef]

60. Vetri, V.; Librizzi, F.; Leone, M.; Militello, V. Thermal aggregation of bovine serum albumin at different $\mathrm{pH}$ : Comparison with human serum albumin. Eur. Biophys. J. 2007, 36, 717-725. [CrossRef]

61. Pereira, L.G.C.; Théodoly, O.; Blanch, H.W.; Radke, C.J. Dilatational Rheology of BSA Conformers at the Air/Water Interface. Langmuir 2003, 19, 2349-2356. [CrossRef]

62. Lu, J.; Su, T.; Thirtle, P.; Thomas, R.; Rennie, A.; Cubitt, R. The Denaturation of Lysozyme Layers Adsorbed at the Hydrophobic Solid/Liquid Surface Studied by Neutron Reflection. J. Colloid Interface Sci. 1998, 206, 212-223. [CrossRef] [PubMed] 